ERNESTINE VAN DER WALL.

\title{
ORTHODOXY AND SCEPTICISM IN THE EARLY DUTGH ENLIGHTENMENT
}

Cartesianism-scepticism-atheism: these are the keywords of the philosophico-theological conflict waged by the Dutch Calvinists during the early years of the Enlightenment. Central to this dispute was the application of Cartesian tenets to theology, an issue which gave rise to a vehement discussion about scepticism and atheism. In the Dutch Reformed church the debate on scepticism in the late seventeenth and early eighteenth centuries thus took place within the conflict over the reception of the "new philosophy".

Another term should also be mentioned here: Cocceianism. Since Cartesianism found such a ready acceptance among those orthodox Reformed theologians who followed the theology of Johannes Cocceius, the Dutch discussion about scepticism was closely connected with this group of liberal divines, who constituted one of the main parties within the Dutch Reformed church. It was the Cocceian theologians, or at least many of them, who, in the second half of the seventeenth century, developed a kind of Cartesian theology, in which-among other Cartesian tenets-universal doubt played an important role. Their view on the application of Cartesianism to theology became a controversial topic: it was one of the major factors in the religious war with their Calvinist brothers, the Voetians, which broke out in the late 1650 s and would continue well into the eighteenth century. In this paper I shall deal with the way in which Cartesianism was received among Dutch Calvinist divines in the early Enlightenment by focusing upon one particular issue which came to occupy a prominent place in Dutch religious polemics in the course of the seventeenth century: the question of universal doubt, or, more specifically, doubt about God's existence. 


\section{DUTCH REFORMED ORTHODOXY AND ATHEISM IN} THE EARLY ENLIGHTENMENT

By the late seventeenth century Dutch Reformed orthodoxy had developed into a complex entity. ${ }^{1}$ The formularies of unity as laid down by the national Synod of Dort (1618-1619) formed its basis. This common ground, however, did not prevent the emergence of a variety of theological and political ideas within the orthodox boundaries. It was this diversity which in due course gave rise to discussions about toleration. Thus one of the main issues raised in the latter part of the seventeenth century was the question of whether those members of the church who taught that every human being should raise doubts - even if only once in his lifeabout God's existence ought to be tolerated. Might such a dangerous, irreligious throng not seduce others into treading upon the path leading first to that perilous phenomenon, scepticism, and then inevitably to that devilish monster: atheism?

Fear of a steady expansion of atheism is one of the characteristics of religious literature in the early Enlightenment. ${ }^{2}$ What exactly the term "atheism" means in early modern times is hard to define. $^{3}$ The concept was seldom intended to include genuine disbelievers, but, mainly because of polemics, it was used to depict

1 Cf. Paul Dibon, "Scepticisme et orthodoxie reformée dans la Hollande du Siècle d'Or" in Scepticism from the Renaissance to the Enlightenment, eds. Richard H. Popkin, Charles B. Schmitt, Wiesbaden: Wolfenbüttler Forschungen 35, 1987, 55-81: p. 55.

${ }^{2}$ For an illuminating treatment of the concept the early Enlightenment, see the "Introduction" by Alan Charles Kors to a volume of essays on this topic: Anticipations of the Enlightenment in England, France and Germany, eds. Alan Charles Kors and Paul J. Korshin, Philadelphia: University of Pennsylvania Press, 1987, pp. 1-6. See also Margaret C. Jacob, "The Crisis of the European Mind: Hazard Revisited" in: Politics and Culture in Early Modern Europe: Essays in Honor of H.G. Koenigsberger, eds. Phyllis Mack, Margaret C. Jacob, Cambridge: Cambridge University Press, 1986, 251-271.

3 For the notion of "atheism" in early modern times, see Wolfgang Philipp, Das Werden der Aufklärung in theologiegeschichtlicher Sicht, Göttingen: Vandenhoeck und Ruprecht 1957; Hans-Martin Barth, Atheismus und Orthodoxie. Analysen und Modelle christlicher Apologetik im 17. Jahrhundert, Göttingen: Vandenhoeck und Ruprecht, 1974; Hans Leube, "Die Bekämpfung des Atheismus in der deutschen lutherischen Kirche des 17. Jahrhunderts" in Hans Leube, Orthodoxie und Pietismus. Gesammelte Studien, Bielefeld: Arbeiten zur Geschichte des Pietismus 13, 1975, 75-88; John Redwood, Reason, Ridicule and Religion. The Age of Enlightenment in England, 1660-1750, London: Thames and Hudson, 1976; Michael J. Buckley, At the Origins of Modern Atheism, New Haven: Yale University Press, 1987; David Berman, A History of Atheism in Britain: From Hobbes to Russell, London: Croom Helm, 1988; Alan Charles Kors, Atheism in France, 1650-1729, Princeton: Princeton University Press, 1990. 
a wide variety of supposedly irreligious views which were inextricably linked to a loose moral life. ${ }^{4}$

Whether or not the atheistic threat was as real as the popularity of apologetic literature against all sorts of "atheists" might seem to indicate, there was undoubtedly a genuine fear of the theological implications of the works by Isaac La Peyrère, Thomas Hobbes, Louis Meyer, Benedictus Spinoza, and Richard Simon. Their views were thought, not without reason, to endanger the status of revealed religion. The attack on miracles and prophecies, such essential proofs of the truth of the Christian religion; questions about the Mosaic authorship of the Pentateuch; the value of biblical chronology; the role of reason in explaining Scripturewere all regarded as casting doubt upon the divine authority of the Bible and the belief in a providential God. They paved the way first to deism, then to scepticism, and finally to atheism.

It was certainly people like La Peyrère, Hobbes and Spinoza whom orthodox Calvinist divines had in mind when they looked for the most prominent representatives of irreligion and antiChristianity, but there was also another phenomenon which they held responsible for the creation of an atheistic climate: Cartesianism. This new philosophy, more than anything else (even more than Spinozism, since this was considered to be the illegitimate offspring of Cartesianism), dominated the debate on irreligion among Dutch Reformed divines in the early Enlightenment. It was Cartesianism, together with Cocceianism, that almost led to a rift within the Reformed church comparable to the schism of 1619 between Remonstrants and Contraremonstrants. How had this religious war come about?

In the early 1640 s an anti-Cartesian party had come into being within the Dutch Reformed church which abhorred the "dangerous novelties" spread by the French Roman Catholic immigrant Descartes. Gisbertus Voetius, professor of theology and the pillar of Calvinist orthodoxy, was its leader. From his base in Utrecht, the anti-Cartesian bastion, Voetius planned a careful strategy to combat Descartes and his "atheistic" ideas. ${ }^{5}$ Then in the $1650 \mathrm{~s}$,

\footnotetext{
"It was commonly believed that "speculative" atheists did not exist, but only "practical" atheists.

${ }_{5}$ On Gisbertus Voetius (1589-1676) and his struggle against atheism and Cartesianism, see René Descartes-Martin Schoock, La Querelle d'Utrecht, textes établis, traduits et annotés par Theo Verbeek, Paris: Les impressions nouvelles, 1988, Th.M.M. Verbeek, "Voetius en Descartes" in De onbekende Voetius.
} 
within the Reformed church, there emerged what we may call a pro-Cartesian party which embraced the new philosophy, although mainly with moderation. These divines were associated with the theology of Johannes Cocceius who, from 1650 till his death in 1669, lectured at Leiden university, for some time regarded as the centre of Cartesianism. ${ }^{6}$

From then on the Dutch Reformed church was divided between these two camps and it seemed as if the times of the Remonstrants and Contraremonstrants had returned, a fact which was not lost on contemporaries. The Voetians loved to call the Cocceians the lawful heirs of Arminius: to strengthen their case the classis Goes went even so far as to draw up five articles in which Cocceian doctrines were condemned. Like their own forefathers, the Contraremonstrants, they wanted to have these new Arminians condemned at a national synod and expelled from the church. In the 1690 s they made a request to the stadholder, King William III (whom they looked upon as the "author pietatis", "defensor fidei" and "impiorum severus hostis") to convoke a national synod in order to achieve this, but he refused, and with this defeat the Voetians entered into decline while the Cocceians became dominant. Not all Reformed divines sided with one or other party: some, such as Samuel Maresius, Balthasar Bekker, and Herman Witsius, did not belong, or at any rate did not want to belong, to either but chose to go their own way, although they did take part in the controversy.

The whole of Dutch Calvinist orthodoxy was involved in this religious war, in which theological, philosophical, political and social factors intervened. What had begun as a dispute between Voetius and Descartes extended into a national conflict between the members of the Reformed church. While Voetius might at first have cherished the illusion that he was fighting against a

Voordrachten wetenschappelijk symposium Utrecht 3 maart 1989, eds. J. van Oort et al., Kampen: kok, 1989, 200-219; Th. Verbeek, "Descartes and Atheism: the Utrecht Crisis", Nederlands Archief voor Kerkgeschiedenis / Dutch Review of Church History 71/2 (1991), 211-233. Th. Verbeek, Descartes and the Dutch. Early reactions to Cartesian Philosophy 1637-1650, Carbondale and Edwardsville: Southern Illinois University Press, 1992, ch. 2.

${ }^{6}$ For Johannes Cocceius (1603-1669), see Gottlob Schrenk, Gottesreich und Bund im älteren Protestantismus vornehmlich bei Johannes Coccejus, Gütersloh: Bertelsmann, 1923 (reprint Giessen: Brunnen-Verlag, 1985); Heiner Faulenbach, Weg und Ziel der Erkenntnis Christi. Eine Untersuchung zur Theologie des Johannes Coccejus, Neukirchen-Vluyn: Neukirchener Verlag, 1973; W.J. van Asselt, Amicitia Dei. Een onderzoek naar de structuur van de theologie van Johannes Coccejus (1603-1669), Ede: ADC, 1988. 
popish enemy, an alien in the Protestant church, he and his followers soon became acutely aware that the enemy had crept into their church and had even won many adherents-and a more intensive anti-Cartesian campaign began. ${ }^{7}$ Not only were academic institutions deeply engaged in it (apart from Leiden, Franeker was an important Cartesian-Cocceian centre), but learned ministers in towns and villages in the country also played a conspicuous part in the quarrel. It was a debate, moreover, carried on among the common people, who were neatly informed about the developments via public sermons. In one of the provinces they even went so far as to replace the usual Sunday afternoon sermon on the Heidelberg Catechism by sermons on the Cocceian-Voetian dispute. Many pamphlets were published in Dutch, so their contents were generally accessible. ${ }^{8}$

A glance at the "catalogues of errors" drawn up by Voetians gives an idea of the main issues. One of them was the "theologia prophetica", which was intensely pursued by Cocceian and Cartesian theologians. Like Henry More, Isaac Newton and others, Cocceian and Cartesian theologians such as Salomon van Til, Johannes van der Waeyen, Frans Burman, Henricus Groenewegen, Abraham Gulich, Taco Hajo van den Honert and his son Johan van den Honert immersed themselves in the study of the books of Daniel and Revelation in order to discover the key with which to understand the past, the present and the future. Their prophetic

7 On the reception of Cartesianism in the Netherlands, see the standard work by C. Louise Thijssen-Schoute, Nederlands Cartesianisme. Avec sommaire et table des matières en français, Amsterdam: Noord-Hollandsche Uitgevers Maatschappij, 1954 (repr. with additional bibliography, edited by Th. Verbeek, Utrecht: HES Uitgevers, 1989); C. Louise Thijssen-Schoute, "Le cartésianisme aux Pays-Bas" in Descartes et le cartésianisme hollandais, eds. E.J. Dijksterhuis et al., Paris: Presses Universitaires de France, 1950; Ernst Bizer, "Die reformierte Orthodoxie und der Cartesianismus", Zeitschrift für Theologie und Kirche 55 (1958), 306-372; Th.A. McGahagan, Cartesianism in the Netherlands, 1639-1676. The New Science and the Calvinist Counter-Reformation, Ann Arbor: University Micro-films, 1976. See also J.A. Cramer, Abraham Heidanus en zijn Cartesianisme, Utrecht: Van Druten, 1889; Josef Bohatec, Die cartesianische Scholastik in der Philosophie und reformierten Dogmatik des 17. Jahrhunderts I, Leipzig: Deichert, 1912; Klaus Scholder, Ursprünge und Probleme der Bibelkritik im 17. Jahrhundert. Ein Beitrag zur Entstehung der historisch-kritischen Theologie, München: Kaiser-Verlag 1966; Pieter Swagerman, Ratio en revelatio. Een theologisch critisch onderzoek naar het Godsbewijs en de Godsleer uit de menselijke ratio en de verhouding van de natuurlijke theologie tot de geopenbaarde theologie bij enige Nederlandse hoogleraren in de theologie of in de filosofie van 1650 tot 1750, Groningen: Faculteit der godgeleerdheid, 1967; Verbeek, Descartes and the Dutch.

${ }^{8}$ See the preface to the Bedenckinge van Timotheus Verinus ... waerin getoont wort hoe ongefondeert de $E$. Broederen sommige geleerde theologanten heterodoxien en nieuwigheden te laste leggen, Leiden 1674. 
theology was intended to serve as an apologetic instrument to ward off the sceptical and atheist assault on Scripture: the accomplishment of biblical prophecies proved the divine authority of the Scriptures. This form of apologetics became as popular as another contemporary beloved apologetic means: physicotheology, and both were simultaneously put forward in the defence of Christianity. ${ }^{9}$

One of the interesting things about the Cocceians is that while on the one hand they embraced Cartesianism, on the other they developed this "prophetic theology". For the Voetians the reason of this association was clear: the Cocceians discovered the same harmony and order in the biblical prophecies as they loved in Descartes' philosophy. Although this apologetic genre did not flourish among the Voetians, we cannot deny that (semi-)millenarian notions were also cherished by many followers of Voetius. Furthermore, both camps had a pietistic strain in their theology, the Voetians being the exponents of the so-called "Further Reformation" ("Nadere Reformatie"), while the pietistic Cocceians were labelled as "serious" Cocceians. Thanks to those pietists on both sides the Voetians and Cocceians would be reconciled in the course of the eighteenth century.

In the late seventeenth century, however, there were sufficient points of debate left to keep these Calvinist brothers at a hostile distance from one another. One of the dominant themes was the relationship between theology and philosophy, so inextricably linked that changes in the one would directly affect the other: new philosophy would bring in new divinity. ${ }^{10}$ This was not lost on the Voetians, who clung to Aristotelian-scholastic philosophy, being,

9 On the "theologia prophetica" of the Cocceians, see Grete Möller, "Föderalismus und Geschichtsbetrachtung im XVII. und XVIII. Jahrhundert", Zeitschrift für Kirchengeschichte 50 (1931), 393-440. See also Ernestine van der Wall, "'Antichrist Stormed': The Glorious Revolution and the Dutch Prophetic Tradition", in The World of William and Mary, eds. M. Feingold, D. Hoak forthcoming. On the scholarly interest in Bible prophecies in 17th-century England, see Richard H. Popkin, "The Third Force in Seventeenth Century Philosophy: Scepticism, Science and Biblical Prophecy", Nouvelles de la Republique des Lettres 1 (1983), 35-64; Richard H. Popkin, 'The 'Incurable Scepticism' of Henry More, Blaise Pascal and Sören Kierkegaard", in Scepticism from the Renaissance to the Enlightenment, 169-184: esp. 170-175; both reprinted in Richard H. Popkin, The Third Force in Seventeenth-Century Thought, Leiden: Brill, 1992.

${ }^{10}$ See the remark by Simon Patrick, A Brief Account of the New Sect of Latitude Men, London 1662, p. 22: "philosophy and divinity are so interwoven by the schoolmen, that it cannot be safe to separate them; new philosophy will bring in new divinity" (quoted in: B.C. Southgate, "Forgotten and Lost": Some Reactions 
however, first of all eclectics." Although he was not a pure anti-scholastic, Cocceius strove only to make use of scriptural terms in theology 12 and was thus not much concerned with the old philosophy - or any philosophy whatsoever, Cartesianism included. He always displayed a certain caution when asked about his views on Cartesianism, and when it was pointed out to him that some of his theological ideas were similar to those of Descartes he merely remarked that he had come to those conclusions long before Descartes. ${ }^{13}$ Nevertheless, he seems not to have been unfavourable to Cartesianism. A polemical writer would call him "un double Descartes". ${ }^{14}$

Most of Cocceius's followers were less cautious about their views on the new philosophy, and contemporaries were struck by the fact that Cocceianism and Cartesianism often went hand in hand: like Samson's foxes they were turned tail to tail, putting a firebrand in the Reformed church between two tails (Judges 15:4, 5). It was said that nobody could be a good Cocceian without being a Cartesian - an observation which was denied by Heidanus. ${ }^{15}$ Apparently this alliance was not of a merely external nature, as has been asserted, both then and later, but was based on philosophico-theological grounds. ${ }^{16}$ At any rate, a Cartesian way of

to Autonomous Science in the Seventeenth Century", Journal of the History of Ideas 50 (1989), 249-268: p. 253).

${ }_{11}$ The eclecticism of the Voetians is emphasized by Jacobus Koelman, who refers to the inaugural oration delivered by the Voetian professor of theology in Leiden, Johannes Hoornbeek. In this respect there may also be some affinity with the Cocceians, since these divines were eclectics too.

12 See also p. 132.

13 Thus Cocceius wrote to his son-in-law Willem Anslaar, a learned Cocceian-Cartesian minister: "Ego professor fui, antequam Cartesius nominaretur: et non putavi ad me pertinere, scire, quid is sentiat. Et ut rem dicam, ipsius sententiam adhuc ignoro; aut, si scivi, oblitus sum. Ignoro etiam qui Theologi sententiam ejus rejecerint; neque id inquiro" (Opera omnia VI, Ep. 170). On Cocceius's view of the relation between theology and philosophy, see Van Asselt, Amicitia Dei, ch. 3; Cramer, Abraham Heidanus, 3-7; Thijssen-Schoute, Nederlands cartesianisme, 30-35.

14 See Pierre de Joncourt, Entretiens sur les differentes méthodes d'expliquer l'Ecriture et de prêcher de ceux qu'on appelle Coccéiens et Voetiens dans les ProvincesUnies. Ou l'on voit quel temperament on doit apporter dans l'explication des types, des allegories, des periodes, des prophéties, et d'autres choses de ce genre.... Amsterdam 1707, p. 22.

15 Abraham Heidanus, Consideratien over eenige saecken onlanghs voorgevallen in de universiteyt binnen Leyden, Leiden 1676, 17.

${ }_{16}$ The alliance between Cocceianism and Cartesianism caused astonishment in the 17th century as well as in later times. Thus Jacques Basnage wrote in his Annales des Provinces-Unies I, The Hague 1726, p. 456: "Ce parti [the Cocceians], foible dans sa naissance, s'apuia des Cartésiens, malgré l'incompatibilité de leurs 
thinking was introduced by the Cocceians into theology, on which it was to exert a deep and prolonged influence. While the Cocceians expected many good things for religion from the new philosophy for religion-it was a perfect means to combat atheism-, the Voetians considered Cartesianism a threat to Christianity which would lead immediately to atheism. The latter found themselves confirmed in their sombre expectations by radical expressions of "Cartesian theology" which came to the fore in the 1660s.

One of the incisive events in the religious conflict was the publication of Louis Meyer's Philosophia Sanctae Scripturae interpres. The year of its publication, 1666, might be regarded as the starting point of a new phase in the history of Dutch Cartesianism. To some contemporaries, such as the Scottish theologian and millenarian John Durie, it was no coincidence that this was the year both of the curious events around the Jewish pseudoMessiah Sabbatai Sevi and the publication of Meyer's book: it was God's will that Christians should now reach agreement among themselves about a firm and infallible rule for the exegesis of Scripture. That rule could be presented to the Jews in the hope that they would also accept it unanimously. Thus Meyer's work opened the door to the unity between Christians and Jews thereby hastening the coming of Christ's millenial kingdom. ${ }^{17}$ However

principes, puisque l'un adopte sans peine un sens mystique, qui dépend de la vivacité de l'esprit, et du feu de l'imagination des Interprètes, et que l'autre a bâti son système sur cette maxime, qu'on ne doit croire que les choses, dont on a des Idées évidentes, claires et distinctes". J.A. Cramer (Abraham Heidanus, 4-13, 156) declares that the alliance was a purely external one. Schrenk (Gottesreich und Bund, 20-21) says that this might be true in Heidanus's case, but that one may wonder whether it can be maintained as a general thesis, adding: "Dies vermöchte nur eine eingehende Geschichte des Coccejanismus herausstellen" (p. 22, note 1). Since such a history still has to be written, it is difficult to make any more specific comment. Thijssen-Schoute is of the opinion that, besides external factors, there are also internal motives for the alliance, see Nederlands Cartesianisme, 34-35, and "Le cartésianisme aux Pays-Bas", p. 241 ("Avouons du moins que les thèmes cartésiens et les thèmes coccéjens se sont trop intimement pénétrés pour que l'on puisse affirmer avec Cramer, que les liens qui les rattachent ont toujours été des liens purement extérieurs). McGahagan goes on in the same line, pointing to the concept of "fides implicita" as the binding factor of the otherwise mysterious association of Cartesianism and Cocceianism" (Cartesianism in the Netherlands, p. 364 ff.). Van Asselt, however, returns to Cramer's view that only external factors brought them together (Amicitia Dei, p. 36).

17 See John Durie's letter to Johann Heinrich Hottinger and Johann Heidegger, 30 January 1667, Thes. Hott. 30 F83, f. 253 r/v (Zentralbibliothek Zürich). 
this may be, it was Meyer's work, with its thesis that Cartesian philosophy provided the one and only perfect method of interpreting Scripture, that showed to shocked contemporaries what the theological implications of Cartesianism really could be. Although Meyer's views on the relationship between philosophy and theology were fiercely attacked, it suddenly became apparent to what extent the new philosophy posed a serious threat to traditional Christianity. In 1673 the Philosophia S. Scripturae interpres was banned by the States of Holland and Westfriesland, while a year later it was forbidden by the Court of Holland (together with Spinoza's Tractatus theologico-politicus, Hobbes's Leviathan and the Socinian Bibliotheca Fratrum Polonorum). ${ }^{18}$

After Meyer's work had caused so much excitement in religious and philosophical circles, the subsequent debate on Cartesianism was marked by a series of episodes. The political events of 1672 (the fall of De Witt and the States' party and the rise of William III and the Orangist party) occasioned a change in the relations between Voetians and Cocceians, the star of the first quickly rising, while the latter were pushed back into a less favourable position. The Cocceians were accused of being pro-French: so fond of the philosophy of a papist Frenchman, why would they not betray to the French enemy their country as well? The Voetians, with William III as their protector, felt sufficiently secure to reinforce their assault on the "innovators" and "rationalists" who paved the way to "impious atheism" within the Reformed church.

The year 1676 thus saw the dismissal of the grand old man of Cartesianism, the nearly 80-year old Leiden professor Abraham Heidanus, while in the same year, through the intervention of William III, two Cocceian-Cartesian ministers, Willem Momma and Johannes van der Waeyen, were dismissed from their Middelburg (Zeeland) posts. ${ }^{19}$ Although 1676 is sometimes considered the culmination of the history of Cartesianism in the Dutch Republic,

${ }^{18}$ In 1669 the Theological Faculty of Leiden expressed its very unfavourable opinion of Meyer's book. Its advice was signed by Heidanus and Cocceius.

${ }_{19}$ After his dismissal from Middelburg Johannes van der Waeyen was appointed professor of theology at Franeker. The more liberal Frisian court felt some rivalry towards William III and sometimes supported the appointment of scholars who were out of favour with William III. Van der Waeyen was one of the beloved targets of the Voetians, since he had been a staunch Voetian before he had gone over to Cocceianism around 1670. During his Voetian period Van der Waeyen had attacked the Cartesians, accusing them of scepticism and atheism. After he had joined the Cocceians the Voetians liked to confront him time and again with his earlier anti-Cartesian observations. 
the story certainly did not end there. In the early 1680 s an episode concerning the Frisian minister David Flud van Giffen gave rise to a prolonged national discussion on Cartesianism and Cocceianism in which many prominent theologians took part. ${ }^{20}$ The Van Giffen affair was soon followed by the case of Herman Alexander Röell, professor in Franeker, whose brand of Cartesian theology would be labelled as dangerous "Röellianism", causing dismay within Calvinist orthodoxy well into the eighteenth century. ${ }^{21}$ Then, in the early 1690s, Balthasar Bekker published his Betoverde Weereld ("The Enchanted World"), the propositions of which were clearly inspired by Cartesianism. ${ }^{22}$ In the first decade of the eighteenth century the Walloon preacher Pierre de Joncourt rekindled the flames by publishing some satirical dialogues between Cocceians and Voetians. ${ }^{23}$ Several years later a fierce dispute arose on Cartesianism and Spinozism between the two Franeker professors Ruardus Andala and Johannes Regius. ${ }^{24}$ Eighteenth-century Calvinist theologians continued to write that Cartesianism had constituted the hot-bed of all libertinisms, including "bastard-Cartesianism" or Spinozism, which flourished in their time. ${ }^{25}$ So Descartes was able to engage people's - polemical-energy in the Dutch Republic until nearly a century after he had come to live there.

All this is familiar to the historian of Dutch Cartesianism. However, the theological aspects of the Dutch debate on Cartesianism have not yet received due attention. A thorough examination of Cocceian theology will throw more light upon the exact nature of the alliance between Cocceianism and Cartesian theology, and may thus show how this complex of theological and philosophical ideas contributed to the moderate Enlightenment so typical of Dutch culture.

${ }^{20}$ On the Van Giffen affair, see Ernestine van der Wall "Profetie en providentie: de coccejanen en de Verlichting" in Kerk en Verlichting, eds. P. Bange et al., Zwolle: Stichting Windesheim 600, 1990, 29-37.

${ }_{21}$ See J. van Sluis, Herman Alexander Röell, Leeuwarden: Fryske Academy, 1989.

${ }^{22}$ See W.P.C. Knuttel, Balthasar Bekker. De bestrijder van het bijgeloof, The Hague: Nijhoff, 1906 (reprint Groningen: Bouma, 1979).

${ }_{23}$ See Pierre de Joncourt, Entretiens (see note 20).

24 On the dispute between Ruardus Andala and Johannes Regius, see ThijssenSchoute, Nederlands cartesianisme, p. 520. In 1725 Regius delivered an inaugural address Pro scepticismo.

${ }_{25}$ Thus the Zeeland minister and polemicist Carolus Tuinman, Korte afschetzing der ysselykheden welke van de Spinozistische vrijgeesten uitdrukkelyk worden geleert...., Rotterdam 1719, pp. 8, 9. 


\section{The Cocceian-Voetian Debate on CaRtesian and SCEPTICAL DOUBT}

Let us now turn to one of the contemporary issues that dominated the late seventeenth-century Dutch debate on Cartesian theology: universal doubt and its application to divine matters. In an earlier stage Cartesian doubt had not been as dominant as it would become later on, because at first Cartesian theologians did not lay much stress on this point and were cautious in handling it. However, with the development of Cartesian theology, and especially since more radical expressions of it had been put forward by men such as Louis Meyer, Louis Wolzogen, and Lambert van Velthuysen, doubt became one of the major themes in the CocceianVoetian dispute. Was it permissible to apply the Cartesian method of doubt to theology? Would methodical doubt not lead inevitably to sceptical doubt, and this in its turn to a denial of God? Should we accept religious propositions only insofar as they are clear and distinct to us? Might God be called a deceiver? Such matters were hotly debated by Dutch divines and led to a seemlingly interminable stream of tracts and sermons dealing with the effects of Cartesian philosophy upon Calvinist theology.

The Cocceians expressed a variety of views on Cartesian doubt. For Cocceius's own opinion we are always referred to a passage in his Considerationes de ultimis Mosis (1650), in which he spoke derogatively about doubt as that "nova pullulans pestis". Doubt prevented man from attaining true knowledge of God. In a letter of 19 March 1661 Cocceius declared that, when writing this passage, he had had the sceptics in mind, not the Cartesians:

Quum ultima Mosis scriberem, multa audiebam garrire de dubitatione. Putabam Scepticismum reduci. Et multi sic loquebantur. Non habebam tunc Cartesii libros; \& illum quoque non nominavi. Eadem illa dubitatio nobis, dum hic fui, turbas dedit. Semper judicavi, Cartesium, dum Aristotelice locutus est de dubitatione, infeliciter locutum esse. Incipiunt, ni fallor, etiam magistri videre ... Caeteroquin Cartesius non vult, de omnibus esse dubitandum, sed, quae distincte \& clare cognoscimus, ea nobis affirmanda \& tenenda judicat. ${ }^{26}$

When, in 1668, a new edition of the Considerationes was being prepared, Frans Burman suggested to Cocceius that he either leave

${ }^{26}$ See Cocceius, Opera anecdota, Ep. 489. See also Thijssen-Schoute, Nederlands Cartesianisme, p. 33; Van Asselt, Amicitia Dei, p. 34. 
this passage out or rewrite it and give it a more favourable turn. Cocceius replied that he did not think Descartes had made a fortunate choice with the word "dubitatio". It was a pity that he had not chosen a scriptural term:

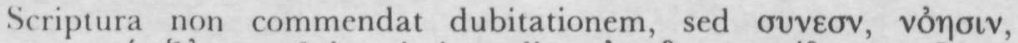

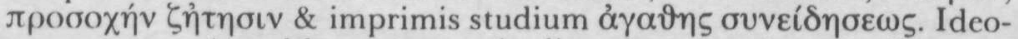
que non tam (quod bona tua venia dicam) propendeo ad tollendum cum paragraphum, quam etiam, si nondum satisfeci, explicandum amplius". 27

Among Cocceius's friends and followers we meet with moderate as well as with more radical views. Prominent Cocceians and Cartesians such as Christoph Wittich, Abraham Heidanus and his son-in-law Frans Burman (who taught in the Voetian stronghold of Utrecht) were convinced that doubt was permissible as an instrument with which arrive at the truth. Heidanus, however, regarded "the injurious opinions of Academicians and Pyrrhonists" as one of the causes of atheism. ${ }^{28}$ Burman observed that it was never permissible to be uncertain about God's existence. We should, however, only assent to this truth on the most solid grounds. Such a doubt was not so much doubt about God's existence as about man's notion of God's existence.

This view was shared by someone like the prominent CocceianCartesian minister of Enkhuizen, Henricus Groenewegen, who interpreted doubt about God's existence as doubt about man himself; about whether he took sufficient note of the reasons which showed him the perfection and necessity of the divine being. According to these men, therefore, doubt about God's existence had to be regarded as subjective rather than as objective. ${ }^{29}$ Salomon van Til, pointing to the dangers of atheism, quoted the French apologist David Derodon in order to show that the most dangerous of the irreligious are those who subtly lead others to raise doubts about divine matters. ${ }^{30}$

Timotheus Verinus gave the following explanation of Cartesian doubt. If it were really true that some theologians taught that we should doubt whether God exists it would be the most horrible heresy. But nobody taught such a doctrine. Verinus explained that

\footnotetext{
27 Cocceius, Opera anecdota, Ep. 441.

${ }^{28}$ Abraham Heidanus, De origine erroris libri octo, Amsterdam 1678, 224-240 (quoted by Cramer, Abraham Heidanus, p. 48).

${ }_{29}$ Frans Burman, Synopsis, 1. 1, c. 14, \$27.

${ }^{30}$ Salomon van Til, Het voorhof der heidenen voor alle ongeloovigen geopent, Dordrecht $1694,4-5$.
} 
Descartes, when involved in a dialogue with a sceptic, wanted to convince him on his own grounds. Descartes had declared he had done this as a philosopher who seeks certitude and truth in nature, and that doubt was to be equated with suspension of judgement. So the crux of the matter was whether a philosopher might examine the reasons in nature for accepting something as true, and whether he might thus prove that there is a God and through examination discover the grounds of this truth, all for the purpose of convincing atheists. ${ }^{31}$

One of the main participants in the Cocceian-Voetian debate on Cartesianism and scepticism was Petrus Allinga, a learned minister in a small village in Noord-Holland. ${ }^{32}$ Allinga, who has hitherto remained somewhat obscure, is an eminent representative of those religious and philosophical thoughts characterized by notions of both Cocceianism and Cartesianism. In philosophical matters he embraced the concepts of Descartes, while in theology he was attracted to the ideas of Cocceius. He declared that the thought of these two men might be extremely useful in order to confirm the doctrine of the Reformed church. ${ }^{33}$ As to the alliance between Cocceianism and Cartesianism Allinga observed that among the Cocceians and Cartesians there reigned a "unio animorum". The causes of this union were manifest-"consensus in fundamentalibus, libertas in philosophicis, veritatum mutua amicitia, unionis necessitas ob communes veritatis hostes" ${ }^{34}$

Allinga emphasized that he did not follow Descartes in every respect. He therefore thought it unfair to derive arguments from Descartes' works in order to attack people like himself. Descartes had not been a member of the Dutch Reformed church and thus could not be presented as a proclaimer of novelties within it,

31 See Bedenckinge van Timotheus Verinus, 50.

${ }^{32}$ For Petrus Allinga (16?-I692), see Nieuw Nederlandsch Biografisch Woordenboek (NNBW) 4, 37-38; Biographisch Woordenboek van protestantsche godgeleerden in Nederland (BWPGN) 1, 85-91; Thijssen-Schoute, Nederlands cartesianisme, 40, 41, 43-48, 525; McGahagan, Cartesianism in the Netherlands, passim. Scholder, Ursprünge und Probleme, p. 146, reckons Allinga, like Balthasar Bekker, among what he calls "the Cartesian middleparty". Allinga was befriended by Bekker who, in a laudatory poem in one of Allinga's works, depicted Wijdenes, the village where Allinga lived, as "the Noordholland Nazareth".

33 Something resembling an autobiographical sketch of Allinga is to be found in the Preface to his Zedige verhandeling van de voornaemste verschil-stukken tusschen de leeraren van de gereformeerde kerk en die haer noemen leeraren van de Augsburgsche Belijdenis, ingesteld door- -..., Leeuwarden 1679.

${ }_{34}$ Petrus Allinga, Fax dissidii extincta seu exercitationes pacificae ad nonnullas quaestiones problematicas, quae hodie in Belgio potissimum moventur, Amsterdam 1682, Preface. 
Allinga insisted -otherwise all the horrible doctrines of the papist scholastics, whose philosophy was so highly esteemed by many Reformed divines, should also be reckoned among the sins of the church. Allinga only wanted to regard as followers of Cartesianism those who belonged to the Reformed church. Other Cartesians, he said, were irrelevant to the debate. ${ }^{35}$

It was the discussion between Allinga and Herman Witsius, caused by the latter's famous Twist des Heeren met sijn wijngaert (1669) that started the debate between the Cartesian theologians and the anti-Cartesians, in which the question of complete doubt played such a major part. In the tracts which appeared during this debate, and which led in their turn to fierce discussions with prominent Voetians such as Melchior Leydekker and Leonardus Rijssenius, Allinga defended the Cartesian method of doubt. As the first of ten "special examples of miraculous and strange novelties" Witsius advanced the proposition that man, in order to attain the truth, should raise doubts about anything, even about God's existence. As the second "strange novelty" he mentioned the proposition that "God might deceive if He wanted to". According to Witsius doubt was not only the suspension of judgement but also regarding matters as false until one was convinced of their truth. This might lead to the abominable conclusion that during this period of doubt we had denied God's existence. ${ }^{36}$

In his reply Allinga laid much stress on the interpretation of the term "dubitatio". In true Cartesian fashion he insisted that "dubitare" meant "to suspend judgement until we have found solid grounds for embracing the truth". ${ }^{37}$ Interestingly enough-and more in the Cocceian tradition-he declared that he himself never used the term "dubitare" in order not to offend his Reformed brothers. ${ }^{38}$ As he pointed out, however, all learned philosophers interpreted "dubitatio" as "suspension of judgement". He referred

${ }^{35}$ Petrus Allinga, Verdeediging van de eer en leer der voormaamste leeraren van Nederland, 1672, p. 229; Seker oudt in waerheydt bevestight en in liefde gesuyvert van de kladde van aenstootelyk nieuw, Amsterdam 1673, 20-21, 26.

${ }_{36}$ Herman Witsius, Twist des Heeren met sijn wijngaert, 1669. On Witsius, see J. van Genderen, Herman Witsius. Bijdrage tot de kennis der gereformeerde theologie, The Hague: De Bres, 1953.

${ }_{38}$ Allinga, Verdeediging, 15-17; Seker oudt, p. 17.

38 Allinga, Fax dissidii, p. 5: "Non male ante anneos aliquot observavit prudentissimus Theologus cl. Coccejus, subtilissimum Cartesium infeliciter fuisse usum vocabulo dubitationis (...) Quamvis vocabulum illud nunqum meum fecerim, ne fratribus essem offensioni, malevolis occasioni detorquendi vocem innocuam, ac pacificis dolori, attamen de voce ea nonnulla dicam, ut palam fiat, quis sit verus hujus controversiae status". 
to Frans Burman and Christophorus Wittichius who agreed with him; but they were not the only ones: Cocceius's son-in-law Willem Anslaar, who, under the pseudonym Philalethius Elieser, wrote an interesting tract on Cocceianism and Cartesianism, defended this view strongly. ${ }^{39}$ Furthermore, Allinga emphasized that Descartes had made a distinction between "doubt" and "falsehood" and had certainly not equated those notions. ${ }^{40}$

As to the charge of scepticism, Allinga pointed out that Descartes had distinguished between "to doubt" and "to persist in doubt", the latter being utterly rejected by the French philosopher. The sceptics, Allinga insisted, did not search for the truth by suspending their judgement; on the contrary, they gave their assent to what they thought was true not on the basis of solid grounds, but rather loosely. This unfounded assent was the cause of sceptical doubt, an incurable fluctuation which tore the sceptical mind apart. Without a well-based assent there would be no true religiosity, no comfort and certainty for man's soul. ${ }^{41}$

According to Allinga, then, Cartesianism was a perfect means to combat scepticism and atheism. Among the most important causes of atheism was the fact that man did not search for the fundamental and evident proofs given by nature of the truth of God's existence from their childhood onwards. Atheism had free play if this truth was not embraced upon solid grounds but merely as some vague rumour heard from one's parents. Man should only assent to the truth of God's existence on solid grounds, suspending his judgement until he can see those grounds. " "What should we do in order to assent to a proposition?", Allinga asked. Was it enough for it to be true in itself, although we do not see it as such? Or should we give our assent because we see that it is true? The first view was nonsensical. If, however, the second proposition was correct, it meant that we should not assent to the truth of God's existence without good reason. ${ }^{43}$ Allinga was convinced that those who did not embrace their religion after a thorough investigation of its fundamental truths would fall into atheism at its first blow. That was why the Cartesian method was so important: it showed the way to certitude.

${ }^{39}$ Philalethius Elieser, Ontdeckinge van de quade trouw en ' $t$ onverstand van Irenaeus Philalethius in sijn bittere antwoord op de vrage: Wat is Cocceanerye?, Amsterdam 1674, 10-11.

${ }^{40}$ Allinga, Seker oudt, p. 23.

41 Allinga, Seker oudt, p. 27.

42 Allinga, Seker oudt, 15-17.

43 Allinga, Seker oudt, 18-19. 
It was as a consequence of the Fall, Allinga maintained, that man raised doubts as to whether God existed. Due to his spiritual blindness he did not see the grounds of this truth as clearly and distinctly as he did before the Fall. Whoever saw those grounds clearly, could be in no doubt any longer. How might one save oneself from this doubt? By embracing the truth of God's existence without any reason? This would not cure doubts, but only feed them. Man could only be helped by searching for solid grounds in order to assent to the truth of God's existence with a sagacious judgement. ${ }^{44}$

To the Voetian charge that he and others taught men to doubt whether there is a God, Allinga replied that it was the Voetians who did that, since they denied that man possessed an innate idea of God and the concept of a perfect Being. Such doctrines led to doubt and atheism, Allinga declared. ${ }^{45}$

Universal doubt was thus one of the central issues advanced in the Cocceian-Voetian debate. The view that man had to raise doubts about God's existence was hotly debated by Dutch divines. Doubt about God's existence implied doubt about divine revelation, since that revelation presupposed the existence of a Revealer. This in its turn implied doubt about those revealed truths such as the Trinity, Christ's mediatorial function, and so on. All this, moreover, would lead to doubt about divine laws and prescriptions, finally undermining worship and piety. ${ }^{46}$

In one of his replies to Allinga, entitled Het aenstootelijcke nieuw in waerheyt en liefde ontdeckt ("Exceptionable Novelties in Truth and Love Discovered"), Witsius dealt extensively with doubt about God's existence. Quoting from Descartes' works he referred, like many Voetians, to the fact that this philosopher had dared to call doubt about God's existence pious and respectable. For Witsius it was clear that Descartes' doubt was to be equated with "being uncertain" and "persisting in doubt", despite the passage quoted by him in which Descartes rejected such an attitude. To doubt was not only "to suspend judgement", as Allinga insisted, but it was also "to be unsure about something" and "to consider anything as false so long as one is in doubt". If we could make a person believe that "dubitatio" meant "suspension of judgement", we might also

\footnotetext{
44 Allinga, Seker oudt, p. 19.

45 Allinga, Seker oudt, p. 29; cf. the Preface to his Zedige verhandeling.

46 See, for example, Petrus van Mastricht, Novitatum cartesianarum gangraena .. . seu theologia cartesiana detecta, Amsterdam 1677, Preface.
} 
teach men to eat hay. Or had the Cartesians not only invented a new philosophy but a new language as well ...? ?7 $^{47}$ "dubitare" really meant this, however, why not just say that we should not assent to important matters, let alone divine matters, without any good reason? In that case I would agree immediately and our conflict would be solved, Witsius declared. ${ }^{48}$ Allinga replied that Witsius had hit the nail on the head: this was exactly what he meant by "dubitatio". He regarded Witsius's interpretation of the term as proof of the fact that he had sided with Allinga and his friends. ${ }^{49}$ Witsius's remark indeed indicated a common ground on which Calvinist and Cartesian rationalism could meet.

Witsius wondered why Descartes so often emphasized that such doubt as he proposed might not be extended to matters of faith? Why all that talk about casting doubt upon matters evident to all? Don't think, reader, Witsius declared in an attempt to ridicule the frightening aspects of sceptical doubts, that those people doubt whether they have hands or feet, head or brains, and so on as a joke-no, they are quite serious about it. Maybe you will think it absurd that a sensible man say to himself "there are no human beings in the world, no bakers, no brewers, no bread, wine, ghosts, etc.; all I have seen, heard, felt, tasted, smelled up hitherto has only been a dream, fruits of my imagination, so I have to consider these things as false". Ridiculous as this might be, Witsius proceeded, it was not impious as long as we did not apply such doubt to God. However, Descartes had not hesitated to do exactly that, saying that as long as man was in doubt about God's existence he should regard this truth as false, as a mere fable, and assert that there is no God. Of course such propositions were detested by Witsius, who approvingly quoted Cocceius's words that it was never permissible, under any circumstances whatever, to doubt whether there is a God. ${ }^{50}$

A systematic treatment of universal doubt is given by one of Allinga's other opponents, the Voetian minister Leonardus Rijssenius in his tract De oude rechtsinnige waerheyt verdonckert en bedeckt door Descartes, Coccejus, Wittich, Burman, Wolzogen, Perizon, Groenewegen, Allinga etc. en nu weder opgeheldert door Leonardus Rijssenius ("The Old

47 Herman Witsius, Het aenstootelijcke nieuw in waerheyt en liefde ontdeckt, Amsterdam 1673, 13-15, 18, 26, 27.

${ }_{48}$ Witsius, Het aenstootelijcke nieuw, p. 26.

49 Allinga, Seker oudt, p. 29.

50 Witsius, Het aenstootelijcke nieuw, 15-17, 25, also referring to Gassendi's critique on Descartes. Witsius quotes from Cocceius' Summa Theologiae c. 8, §25. 
Orthodox Truth Darkened and Covered by Descartes etc. and Now Rediscovered by -..."). ${ }^{51}$ Rijssenius's method is first to give a Cartesian proposition and then his own reply to it. In the 42 propositions on doubt, which are to be found in the first chapter significantly entitled "Cartesian doubt paves the way to atheism", Rijssenius gives quotations from works by Descartes, Bassecour, Clauberg, Wittichius, Groenewegen, Burman, and above all Allinga.

The first proposition concerns the observation that he who seeks the truth should cast doubt upon anything once in his life. Rijssenius denies that the method of doubt is necessary to gain the truth: we can have sure knowledge about matters which we never call into question. Doubt is the opposite of faith: they have nothing to do with each other. Rijssenius also denies that we should be in doubt in order to clear our mind of any prejudices and false opinions: false opinions should certainly be rejected, but does this mean that we should reject everything? Should we also be in doubt about true opinions? Is this not rooting up the wheat with the tares (Matthew 13: 29)? The proposition that we should raise doubts in order to prevent errors is countered by the observation that if we are in doubt, we are in error. ${ }^{52}$

The major part of this chapter on Cartesian doubt is devoted to doubt about God's existence. Naturally Rijssenius denies that such doubt is permissible. Man does well if he believes that there is one God (James 2: 19), and badly if he questions it. Doubt can be equated with unbelief. He who is in doubt whether there is a God is without God and a Saviour during that time. (Eph. 2:12; 3:12, 17). Rijssenius is shocked by the proposition advanced by Burman and Allinga that we should embrace the truth of God's existence only on the most solid grounds. This is a flagrant attack on God's authority, for according to these theologians we are not allowed to say that there is a God on the basis of God's Word: they proclaim that we should first investigate whether God's Word is true. The Cartesian theologians who believe that such a truth might only be accepted because man sees a reason to do so imply, as Rijssenius points out, that children and simple folk who are unable to undertake such an investigation are not allowed to embrace the truth, and that they may not be told by others what to believe. Now this is

${ }^{51}$ For Leonardus Rijssenius (ca. 1636-ca. 1696), see NNBW 4, 1190; Cramer, Heidanus, pp. 128, 137-138; Thijssen-Schoute, Nederlands cartesianisme, pp. 40, 41, 447. In this tract, which is dedicated to the Grand Pensionary Gaspar Fagel, he counted 383 Cartesian and 176 Cocceian errors.

52 Rijssenius, De oude rechtsinnige waerheyt verdonckert, pp. 1, 2. 
sheer nonsense. Rijssenius declares, insisting that belief does not require any proofs from nature. Belief precedes all investigation. Finally, Allinga's suggestion that it is not permissible to be in doubt within the boundaries of the church but only where one seeks the truth, leads Rijssenius to declare that, if this were so, a philosopher or a doubter could not be a member of the church and that such people might be excommunicated. This was exactly what Rijssenius wanted: to have the Cocceian-Cartesian divines driven away from the Reformed church. ${ }^{53}$

As for the interpretation by Clauberg and Allinga of "dubitare" as suspension of judgement, Rijssenius insisted that even if to doubt might be explained in this way, it was still sinful, because it implied first lack of belief, and secondly that one did not have knowledge of God, which is a $\sin$ (1 Cor. 15: 34). Allinga himself had declared that man's doubts about God were the consequence of the Fall. Well then, they were sinful, Rijssenius concluded, adding that such a suspension of judgement also suspended the works of love, fear and obedience to God and thus turned man into a practical atheist. ${ }^{54}$

Rijssenius returned to an issue which was also advanced by Witsius and other anti-Cartesians about the equation of doubt and falsehood: if we considered the issue about which we doubted false during the time we doubt, the truth of God's existence might also be regarded as false during that period. How long could this doubt last? Wittichius, Groenewegen, and Allinga had replied: until we are fully assured. Rijssenius concluded that the Jews consequently did not sin when they did not embrace Jesus as their Saviour so long as they saw no reason for doing so. Allinga had declared that a Jew should not simply believe that Jesus was the true Messiah, but should suspend his judgement until he saw solid grounds for assenting to this truth. Rijssenius insisted, however, that during this suspension the Jews remained the property of the devil. This way of reasoning, he added, also implied that the Socinians did not sin when they did not accept the Trinity and the resurrection of the flesh and so on, and that they were not doomed for not accepting those truths. ${ }^{55}$

Rijssenius's attack on Allinga and other Cocceians and Cartesians was soon followed by assaults by Melchior Leydekker and

${ }^{53}$ Rijssenius, De oude rechtsinnige waerheyt verdonckert, 3-10.

${ }_{54}$ Rijssenius, De oude rechtsinnige waerheyt verdonckert, p. 4.

55 Rijssenius, De oude rechtsinnige waerheyt verdonckert, pp. 5, 7. Allinga's remarks about the Jews and the suspension of judgement are repeated by Van Mastricht, who tells that he read these remarks filled with horror (see Gangraena, 32-33). 
Voetius's successor, Petrus van Mastricht. Leydekker accused the "innovators" of "Scepticismus, Atheismus, Apostasia a fide Reformatae Ecclesiae". ${ }^{56}$ Due to the influence of Cocceian theology and Cartesian philosophy the greatest mysteries of the faith had been so forged on the anvil of novelty as not to bear the faintest resemblance to the Confession of faith any more. Leydekker implored the States General to put an end to the spread of this cancer. ${ }^{57}$ Allinga in his turn accused Leydekker of ignorance, since he did not seem to know that "dubitatio" was in itself an innocent word, which had always been used with caution by philosophers. Its meaning had been distorted by those who did not love the truth. To the inexpert it might mean an "ambigua fluctuatio mentis inter quaedam extrema", but to those "studiosi" who sought the truth, it meant a suspension of judgement and a close scrutiny of the truth. ${ }^{58}$ Van Mastricht's Novitatum Cartesianarum Gangraena .... seu theologia cartesiana detecta (despite its title a moderate and lucid, systematic treatment of Cartesian and Cocceian matters) started with an extensive attack on Cartesian doubt in which he advanced more or less the same arguments which had been put forward by his fellow Voetians. ${ }^{59}$

Thus the pattern set by Voetius to equate Cartesianism with atheism was enthusiastically upheld by his followers who, more than an earlier generation of anti-Cartesians, stressed the atheistic implications of Cartesian doubt.

\section{CONCLUSION}

The Cocceian-Voetian conflict offers an instructive insight into the reception of Cartesianism in the orthodox Calvinist world of the

\footnotetext{
56 Melchior Leydekker, Fax veritatis seu exercitationes ad nonnullas controversias, quae hodie in Belgio potissimum moventur, multa ex parte theologico-philosophicae. Praefixa est praefatio de statu Belgicae Ecclesiae et suffixa dissertatio de providentia Dei, Leiden 1677. This tract is dedicated to William III. For Melchior Leydekker (1642-1721), see NNBW 4, 910-913; BWPGN 5, 775-785; Bizer, "Die reformierte Orthodoxie", 363-371; Scholder, Ursprünge und Probleme, pp. 141, note 39, 145; Thijssen-Schoute, Nederlands cartesianisme, 450-451. Leydekker regarded David Joris, Spinoza and Hobbes as the three impostors.

${ }^{57}$ See the preface to his $D e$ verborgentheid des geloofs eenmaal den heiligen overgelevert, Rotterdam 1709.

${ }_{58}$ Allinga, Fax dissidii extincta, pp. 5, 6.

59 Petrus van Mastricht, Novitatum Cartesianorum Gangraena, Amsterdam 1677. This work is dedicated to William III. For Van Mastricht (1630-1706), see NNBW 10, cc. 591-592; Bizer, "Die reformierte Orthodoxie", 357-362; Scholder, Ursprünge und Probleme, pp. 46, note 56, 136, 141, 145. Thijssen-Schoute, Nederlands cartesianisme, pp. 450, 489.
} 
early Enlightenment. By focusing on Cartesian doubt as one of the major issues in this debate, we can see how it made seventeenthand eighteenth-century Calvinist divines acutely aware of the danger of irreligion. Both parties, Voetians as well as Cocceians, were deeply engaged in the struggle against irreligion. Each interpreted this phenomenon in their own way, however, and attempted to find a convincing means of defending Christianity. The Voetians feared that "Cartesian theology" as developed by the Cocceians would undermine Calvinist orthodoxy. Perhaps they saw the dangers of the sceptical challenge to orthodox theology more clearly than the Cocceians.

The Cocceians were convinced that the certainty offered by Cartesianism would reinforce the Christian religion and thus convince the atheists of the truth of Christianity. Uncertainty, caused by lack of independent investigation of fundamental religious truths, was seen by these divines as a major factor contributing to the growth of atheism. According to them the only way out of this crisis was to apply the Cartesian method of doubt to theology. They thus brought about a severe crisis within Calvinist orthodoxy itself, a crisis that changed the face of Dutch Reformed orthodoxy for good. By their attempt to create a synthesis between Calvinism and Cartesianism the Cocceians made a considerable contribution to the development of the rationalistic supranaturalism of the Calvinist Dutch Enlightenment. Besides Cartesianism the Cocceians provided another way out of the religious crisis of their day by developing a "prophetic theology". In this respect they can be seen as the Dutch representatives of international scholarly interest in the "studium propheticum" which captured so many minds in the age of the Enlightenment.

So when the French Calvinist Pierre Bayle emerged on the Dutch scene and prepared his Dictionnaire historique et critique there were vehement discussions going on among Dutch Calvinists about scepticism. It was this Cocceian-Voetian debate on Cartesianism (its bastard, Spinozism, included) that constituted a major part of the Dutch historical background against which Bayle's discussion of the subject must be seen. ${ }^{60}$

${ }^{60}$ Cf. Elisabeth Labrousse, Pierre Bayle II: Héterodoxie et rigorisme, The Hague: Nijhoff, 1964, ix-x; Jacob, "Hazard revisited", 260 f. 